\begin{tabular}{|} 
Ambiente \& Água - An Interdisciplinary Journal of Applied Science \\
ISSN 1980-993X - doi:10.4136/1980-993X \\
www.ambi-agua.net \\
E-mail: ambi.agua@gmail.com
\end{tabular}

\title{
Future scenarios of thermal bioclimatic conditions in a humid tropical city under urban development
}

\author{
ARTICLES doi:10.4136/ambi-agua.2092
}

Received: 07 Feb. 2017; Accepted: 08 Jul. 2018

\author{
Vicente de Paulo Rodrigues da Silva ${ }^{1 *}$; Joel Silva Santos ${ }^{2}$; \\ Eduardo Rodrigues Viana de Lima²; Romildo Morant de Holanda ${ }^{3}$; \\ Enio Pereira de Sousa'; Lincoln Eloi de Araújoº \\ ${ }^{1}$ Universidade Federal de Campina Grande (UFCG), Campina Grande, PB, Brasil \\ Departamento de Ciências Atmosféricas (DCA). E-mail: vicente.paulo@ufcg.edu.br, enio.souza@ufcg.edu.br \\ ${ }^{2}$ Universidade Federal da Paraíba (UFPB), João Pessoa, PB, Brasil \\ Departamento de Engenharia e Meio Ambiente (DEMA).E-mail: joelgrafia.santos@gmail.com, \\ eduvianalima@gmail.com, lincolneloi@yahoo.com.br \\ ${ }^{3}$ Universidade Federal Rural de Pernambuco (UFRPE), Recife, PB, Brasil \\ Departamento de Tecnologia Rural (DTR). E-mail: romildomorant@gmail.com \\ ${ }^{*}$ Corresponding author
}

\begin{abstract}
Urbanization modifies the heat balance in urban areas and has negative effects on landscape, aesthetics, energy efficiency, human health and the inhabitants' quality of life. This work evaluated future scenarios of bioclimatic conditions for João Pessoa, a humid tropical city in Northeast Brazil. The scenarios were determined based on trends in air temperature, relative humidity and wind speed for the time period from 1968 to 2015. The study was performed for two distinct periods of three months each (dry and wet seasons) using data from weather stations equipped with thermo-hygrometers and cup anemometers located in nine representative areas of the city. Trends in air temperature, relative humidity, wind speed, and effective temperature index (ET index) time series were evaluated using the Mann-Kendall test. Results indicated that the air temperature showed an increasing trend of $0.34^{\circ} \mathrm{C} /$ decade, whereas the relative humidity showed a decreasing trend of $0.49 \% /$ decade and the wind speed values ranged from $1.3 \mathrm{~ms}^{-1}$ to $3.80 \mathrm{~ms}^{-1}$. These trends are statistically significant according to the Mann-Kendall test $(\mathrm{p}<0.05)$. The air temperature increased between the 1980s and 2010s, which corresponds to a period of rapid urbanization of the city. Future environmental conditions in João Pessoa will be determined in accordance with the urbanization processes.
\end{abstract}

Keywords: Mann-Kendall test, thermal comfort, urban climate.

\section{Cenários futuros das condições bioclimáticas térmicas de uma cidade tropical úmida sob o aspecto de desenvolvimento urbano}

\section{RESUMO}

O processo de urbanização modifica o balanço térmico nas áreas urbanas e tem efeitos negativos na paisagem, na estética, na eficiência energética, na saúde humana e na qualidade de vida dos seus habitantes. O objetivo principal deste trabalho foi avaliar os cenários futuros das condições bioclimáticas de João Pessoa, uma cidade tropical úmida localizada no Nordeste 
do Brasil. Os cenários foram determinados com base nas tendências da temperatura do ar, velocidade do vento e da umidade relativa para o período de 1966 a 2015. Este estudo foi realizado durante dois períodos distintos de três meses cada (estação seca e estação úmida) usando dados da estação meteorológica equipada com um sistema termo-higrômetro e anemômetro de concha localizados em 9 áreas representativas da cidade. A tendência nas séries temporais de temperatura do ar, umidade relativa, velocidade do vento e do índice de temperatura efetiva (ET índice) foi avaliada usando o teste de Mann-Kendall. Os resultados indicaram que a temperatura do ar mostra uma tendência crescente de $0,34^{\circ} \mathrm{C} /$ década, enquanto a umidade relativa apresenta uma tendência decrescente de 0,49\% /década e os valores da velocidade do vento variam de $1,3 \mathrm{~ms}^{-1}$ a $3,80 \mathrm{~ms}^{-1}$. Essas tendências são estatisticamente significativas de acordo com o teste de Mann-Kendall ( $\mathrm{p}<0,05)$. A temperatura do ar aumentou entre os anos de 1980 e 2010, o que corresponde a um período de rápida urbanização da cidade. As futuras condições ambientais em João Pessoa serão determinadas de acordo com o processo de urbanização.

Palavras-chave: clima urbano, conforto térmico, teste de Mann-Kendall.

\section{INTRODUCTION}

Since microclimatic conditions have a major influence on people's comfort, the issue of outdoor thermal comfort has attracted wide attention in recent years. An estimated three billion people living in urban areas throughout the world are directly exposed to problems related to urban heat island intensity (UHI), which are expected to increase significantly in the near future (Tong et al., 2005; Memon et al., 2008). Several studies have addressed this theme in several different urban climates due to the worldwide severity of the problem, and a wide range of literature is available on the subject (Silva et al., 2010; Salvati et al., 2017; Lobaccaro et al., 2017; Rafael et al., 2017).

The temporal and spatial behavior of air temperature, relative humidity and wind speed are mainly affected by meso- and micro-scale differences in the natural and artificial morphology (Gulyás et al., 2006; Han et al., 2009; Matzarakis et al., 2010). These effects are significant for different levels of regional and urban planning, such as the design of urban parks, assessment of radiation conditions in urban canyons, and a variety of other applications. The growth of a metropolitan area and rise in air pollution levels lead to increases in urban air temperature, energy consumption and heat stress (Krüger et al., 2011; Veremchuk et al., 2016). One of the possible causes of these environmental problems is the drastic reduction of green spaces within cities. Therefore, as cities expand, land use planning becomes critical for determining environment quality because changes in land use from green areas to newly built structures result in changes in the natural surface of the earth (Jusuf et al., 2007; Wu et al., 2016). Meteorological variables, including solar radiation, air temperature, relative humidity, and wind speed have a significant bearing on human comfort and the perception of indoor and outdoor conditions. Specifically, the effect of air velocity on the thermal sensation depends on the environmental temperature. For example, at temperatures below $32^{\circ} \mathrm{C}$, increases in air velocity reduce the sensation of heat, whereas at temperatures between approximately $33^{\circ} \mathrm{C}$ and $37^{\circ} \mathrm{C}$, air velocities do not significantly affect the thermal sensation (Robaa, 2003; Yu et al., 2006). Impervious surfaces can contribute to the formation of UHI, which has significant adverse effects on the quality of the urban environment and the sustainable development of cities. Because vegetation can mitigate the effects of UHIs caused by artificial urban land uses, the UHI problem is more severe in cities with large populations and extensive economic activities (Tseliou et al., 2010). 
The basic hypothesis of this study is that changes in land from green areas to impervious surfaces in a city affect the absorption of solar energy, and changes in wind speed patterns due to buildings results in changes in air temperature and, consequently, changes in human discomfort perception. Since over $50 \%$ of the world's population live in urban areas, it is important to be able to project future bioclimatic conditions in outdoor spaces. Our study predicts future thermal comfort scenarios for the studied region based on changes in air temperature and relative humidity. This analysis is broadly divided into trend and regression analyses for obtaining the spatial configuration of thermal comfort during dry and rainy seasons. This work provides residents, city planners and governments with a methodology that supports the development of a more comfortable city area.

\section{MATERIALS AND METHODS}

\subsection{Study area}

The city of João Pessoa is located at latitude $-7^{\circ} 14^{\prime} 29^{\prime \prime}$ and longitude $-34^{\circ} 47^{\prime} 36^{\prime \prime}$ in the tropical humid climate of Brazil. The predominant vegetation type is Atlantic Forest fragments. The city is bounded by the Atlantic Ocean to the east and experiences the influence of several important large-scale precipitation mechanisms due to its location, such as the Atlantic intertropical convergence zone, upper air cyclonic vortex and cold fronts (Kolotroni and Giridharan, 2008). João Pessoa lies on a relatively flat coastal plain and has an average elevation of $33 \mathrm{~m}$. The annual average temperature ranges between $21^{\circ} \mathrm{C}$ and $31^{\circ} \mathrm{C}$, and the normal annual rainfall is approximately $1800 \mathrm{~mm}$ (Silva et al., 2006). The dry season generally occurs between January and June, and the rainy season occurs between July and December. The meteorological data for trend analysis in wind speed, air temperature and relative humidity were provided by the Brazilian National Institute of Meteorology (Inmet, in Portuguese). Before conducting the analysis, the quality and adequacy of data were assessed. The data at each measurement site were acquired at hourly intervals.

\subsection{Measurements}

Measurements of air temperature, relative humidity and wind speed were performed in nine zones that were chosen to represent the most densely populated areas and various types of land cover in the urban spaces and rural areas surrounding the city (Table 1). Mata do Buraquinho (P01) was adopted as the reference area in this study due to its high-density Atlantic forest vegetation. This vegetation type clearly distinguishes that site from the other observational areas, whose locations are surrounded by high and low buildings that shade them during certain periods of the day.

Table 1. Measurement points within the city of João Pessoa, Brazil. The latitudes and longitudes are shown using the Universal Transverse Mercator (UTM) geographic coordinate system. Altitudes are shown in meters.

\begin{tabular}{lcccc}
\hline Urban zones & Point & Latitude & Longitude & Altitude (m) \\
\hline Mata do Buraquinho & P01 & 9210910 & 0294473 & 18 \\
Bairro Expedicionários & P02 & 9212248 & 0295307 & 54 \\
Bairro Manaíra & P03 & 9213966 & 0297168 & 13 \\
Bairro Cabo Branco & P04 & 9212232 & 0298053 & 09 \\
Bairro Mangabeira & P05 & 9205666 & 0296918 & 50 \\
Bairro Cruz das Armas & P06 & 9210044 & 0291631 & 47 \\
Bairro Alto do Mateus & P07 & 9210524 & 0288930 & 45 \\
Bairro Centro & P08 & 9205666 & 0296918 & 50 \\
Bairro Bancários & P09 & 9209252 & 0297368 & 18 \\
\hline
\end{tabular}


Davis Weather Stations were installed at nine points throughout the city and were supplied with anemometers and thermo-hygrometers for measurements of wind speed, air temperature and relative humidity (Figure 1). The data at each measurement site were recorded hourly. The field measurements were performed at the urban and rural areas from January $5^{\text {th }}$ to March $12^{\text {th }}$, 2015 (representing the dry season) and from June $5^{\text {th }}$ to August $24^{\text {th }}, 2015$ (representing the rainy season). In addition, daily data of air temperature, relative humidity and rainfall from a typical meteorological observation station during the period of 1968-2015 were used to conduct a comprehensive temporal analysis. An analysis was performed to investigate the influence of various land use types that cause an increase in urban temperature. The percentage of land cover was obtained according to the methodology presented by Katzschner et al. (2006) for the following land cover types: (i) ceramic roof tile; (ii) asbestos roof tiles; (iii) aluminum roof tiles; (iv) body of water 1 (swimming pool); (v) body of water 2 (rivers and sea); (vi) asphalt pavement; (vii) concrete pavement; (viii) bare soil; (ix) bare soil + low vegetation; and (x) vegetation.

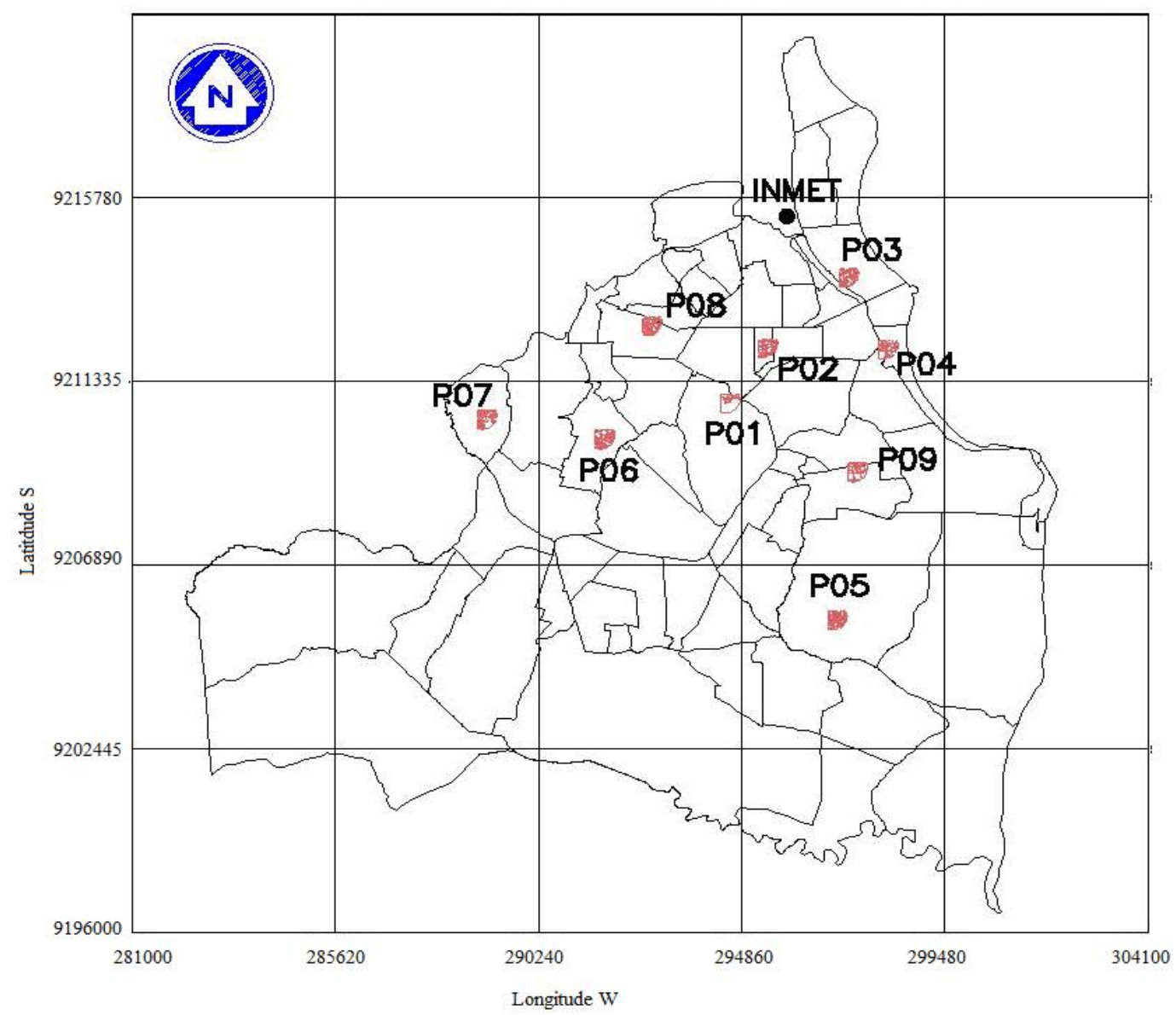

Figure 1. Locations of the measurement points and the meteorological station (INMET) within the study area. The latitudes and longitudes are shown using the Universal Transverse Mercator (UTM) geographic coordinate system. Altitudes are shown in meters.

\subsection{Comfort index}

The human discomfort level within the study area was evaluated through the effective temperature index (ET). The ET index, adapted by Li and Chan (2000), has been used worldwide to assess the effects of thermal environment on the human body as follows (Equation 1): 
$E T=37-\frac{37-T}{0.68-0.0014 R H+\frac{1}{1.7+1.4 \vartheta^{0.75}}}-0.29 T(1-0.01 R H)$

where $v$ is wind speed $\left(\mathrm{m} \mathrm{s}^{-1}\right)$ at $1.2 \mathrm{~m}$ above the ground, $\mathrm{T}$ is air temperature $\left({ }^{\circ} \mathrm{C}\right)$ and $\mathrm{RH}$ is relative humidity (\%). The ET index is suitable for open spaces and describes the extent of thermal loading under several meteorological conditions.

\subsection{Mann-Kendal test}

The World Meteorological Organization (WMO) recommends using the Mann-Kendall nonparametric test (Mann, 1945; Kendall, 1975) for assessing trends in environmental time series data. This test consists of comparing each value of a time series with the remaining values in sequential order. The number of instances for which the remaining terms are greater than that being analyzed is counted. This test is based on the statistic S, which is defined as (Equation 2):

$S=\sum_{i=1}^{n} \sum \operatorname{sign}\left(x_{i}-x_{j}\right)$

where $\mathrm{x}_{\mathrm{i}}$ to $\mathrm{x}_{\mathrm{j}}$ are the sequential data values, $\mathrm{n}$ is the length of the time series and the sign of $\left(x_{i}-x_{j}\right)$ is -1 for $\left(x_{i}-x_{j}\right)<0,0$ for $\left(x_{i}-x_{j}\right)=0$, and 1 for $\left(x_{i}-x_{j}\right)>0$. The mean E[S] and variance $\mathrm{V}[\mathrm{S}]$ of statistic $\mathrm{S}$ are given as (Equations 3 and 4):

$E[S]=0$

$\operatorname{Var}[S]=\frac{n(n-1)(2 n+5)-\sum_{p=1}^{q} t_{p}\left(t_{p}-1\right)\left(2 t_{p}+5\right)}{18}$

where $t_{p}$ is the number of equal occurrences for the $\mathrm{p}^{\text {th }}$ value, and $\mathrm{q}$ is the number of equal values. The second term represents an adjustment for equal or censored data. The standardized test statistic $\left(\mathrm{Z}_{\mathrm{MK}}\right)$ is computed as Equation 5.

$Z_{M K}=\left\{\begin{array}{l}\frac{s-1}{\sqrt{\operatorname{Var}(S)}} \text { if } S>0 \\ 0 \text { if } S=0 \\ \frac{S+1}{\sqrt{\operatorname{Var}(S)}} \text { if } S<0\end{array}\right.$

Comfort condition was established using the ET index with the objective of proposing the comfort limits valid for the study area. A thermal sensation assessment test based on responses from structured questionnaires was used for obtaining the rating scales ranging from uncomfortable to comfortable (Table 2). A similar methodology was applied by Krüger and Drach (2017) to define ranges and performance of UTCI (Universal Thermal Climate Index) in downtown Rio de Janeiro.

The presence of a statistically significant trend is evaluated using the ZMK value. This statistic is used to test the null hypothesis that no trend exists. A positive ZMK value indicates an increasing trend, whereas a negative value indicates a decreasing one. To test for either increasing or decreasing monotonic trends at the p significance level, the null hypothesis is rejected if the absolute value of ZMK is greater than ZMK1-p/2, which is obtained from a standard normal cumulative distribution table. In general, the significance levels of $p=0.01$ and 0.05 are applied. Least-squares linear regression was used to evaluate an increasing or a decreasing slope of trends in air temperature, relative humidity, wind speed, and ET index time series. Based on the trend in ET time series, it was possible to establish the scenarios for the 2020s, the 2030s, the 2040, the 2050s and the 2060s for the annual period and for the dry and the rainy seasons within the study area. The Mann-Kendall nonparametric test was used to verify the significance level of the time series trend.

\section{IPABH}

Rev. Ambient. Água vol. 13 n. 5, e2092- Taubaté 2018 
Table 2. Effective temperature index (ET) classification range adjusted to the climatic conditions of the city of João Pessoa.

\begin{tabular}{ccc}
\hline Number range & $\mathrm{ET}\left({ }^{\circ} \mathrm{C}\right)$ & Comfort conditions \\
\hline 1 & $\mathrm{ET}<24.0$ & Comfortable \\
2 & $24.0 \leq \mathrm{ET} \leq 26.0$ & Partially comfortable \\
3 & $26.0<\mathrm{ET}<28.0$ & Uncomfortable \\
4 & $\mathrm{ET} \geq 28.0$ & Very uncomfortable \\
\hline
\end{tabular}

\section{RESULTS AND DISCUSSION}

The occurrence of maximum and minimum values of the ET index and the thermal variations during both the dry and rainy seasons are summarized in Table 3 . The maximum and the minimum air temperature are not substantially different in both seasons. The thermal amplitude varies from 9.6 to $10.8^{\circ} \mathrm{C}$ during the dry season and from 9.5 to $11.5^{\circ} \mathrm{C}$ during the rainy season. During the rainy season, a temperature maximum occurs at point P08, and a minimum occurs at points $\mathrm{P} 04$ and P05. The air temperature increases rapidly in the mornings and reaches a maximum at approximately 14:00 LT (local time). The relative humidity shows an inverse relationship with temperature: the relative humidity decreases quickly from the early morning hours, and the lowest values are observed concurrent with the highest temperatures. The variability in these parameters corresponds to minimum ET values during the first hour of the day; this effect is most pronounced on January 24th during the dry season and on August 16th during the rainy season. The thermal perception commonly indicates a greater level of discomfort during the daytime in tropical regions with a maximum level of discomfort between 11:00 to 15:00 LT. Accordingly, heat stress increases until approximately 14:00 LT, although local differences occur between the seasons. Similar results were obtained by Gulyás et al. (2006), who assessed the microclimatic and human comfort conditions of the urban environment of a small city in Hungary.

The reference point (P01) has the highest density of vegetation and lowest ET during both seasons (Mata do Buraquinho). Although point P03 (Manaíra) is located near the beach, this site has the highest ET value (Table 4) due to a low percentage of type IX land cover (vegetation) and a high percentage of concrete pavement and ceramic roofing tiles (Table 5). This result does not agree with the observations of $\mathrm{Xu}$ et al. (2010), who found that a water body can effectively improve the human comfort level in the littoral zone during the hightemperature period of a hot summer day. This difference can be attributed to multiple factors, including the amount of impermeable areas with asphalt and concrete pavement, the number of high buildings and the lack of vegetation.

As illustrated by our analysis, when the nights are hot and humid throughout the dry season, uncomfortable conditions prevail during most of the daylight hours due to abundant solar radiation, which provides an additional heat load. In contrast, the interception of radiation by clouds and evaporation from wet surface during the rainy season results in a comfortable thermal sensation in the urban environment. The percentage of land cover for each experimental point is presented in Table 5. As shown in Tables 4 and 5, the ET index decreases when the amount of vegetative area increases, thereby resulting in a significant improvement in the human comfort level. Similar results were obtained by Xu et al. (2010) when they evaluated human thermal comfort near an urban water body in Shanghai, China. They found that vegetation significantly expanded the littoral comfort zone. 
Table 3. Time of occurrence of the maximum and minimum Effective Temperature index (ET) values and the thermal amplitude during the dry and rainy seasons for the study area in 2015.

\begin{tabular}{|c|c|c|c|c|c|}
\hline \multirow{3}{*}{ Points } & \multicolumn{4}{|c|}{ Effective temperature index $(\mathrm{ET})\left({ }^{\circ} \mathrm{C}\right)$} & \multirow{3}{*}{ Thermal amplitude $\left({ }^{\circ} \mathrm{C}\right)$} \\
\hline & \multicolumn{2}{|c|}{ Maximum value } & \multicolumn{2}{|c|}{ Minimum value } & \\
\hline & Date & Hour & Date & Hour & \\
\hline \multicolumn{6}{|c|}{ Dry season } \\
\hline P01 & March 10 & 11:00:00 & February 28 & 05:00:00 & 09.9 \\
\hline P02 & February 2 & 13:00:00 & February 13 & 09:00:00 & 09.7 \\
\hline P03 & February 25 & 14:00:00 & January 24 & 06:00:00 & 10.6 \\
\hline P04 & March 10 & 14:00:00 & January 24 & 05:00:00 & 10.2 \\
\hline P05 & February 25 & 11:00:00 & January 24 & 05:00:00 & 09.8 \\
\hline P06 & February 19 & 13:00:00 & January 24 & 05:00:00 & 10.7 \\
\hline P07 & February 25 & 13:00:00 & January 24 & 05:00:00 & 10.8 \\
\hline P08 & February 25 & 14:00:00 & January 24 & 05:00:00 & 09.9 \\
\hline P09 & February 25 & 13:00:00 & January 24 & 05:00:00 & 10.6 \\
\hline \multicolumn{6}{|c|}{ Rainy season } \\
\hline P01 & June 23 & 11:00:00 & August 16 & 06:00:00 & 10.6 \\
\hline P02 & June 23 & $12: 00: 00$ & August 16 & 06:00:00 & 09.8 \\
\hline P03 & August 4 & 14:00:00 & August 16 & 06:00:00 & 09.9 \\
\hline P04 & June 23 & $13: 00: 00$ & August 16 & 06:00:00 & 09.5 \\
\hline P05 & June 23 & 10:00:00 & August 16 & 06:00:00 & 09.5 \\
\hline P06 & June 7 & $15: 00: 00$ & August 16 & 06:00:00 & 10.2 \\
\hline P07 & June 23 & $13: 00: 00$ & August 16 & 05:00:00 & 10.9 \\
\hline P08 & August 4 & $13: 00: 00$ & August 16 & 06:00:00 & 11.5 \\
\hline P09 & June 21 & $13: 00: 00$ & August 16 & 06:00:00 & 10.4 \\
\hline
\end{tabular}

Table 4. Average, maximum (Max) and minimum (Min) values of air temperature, relative humidity and Effective Temperature index (ET) during the dry and rainy seasons for the study area.

\begin{tabular}{|c|c|c|c|c|c|c|c|c|c|}
\hline \multirow{2}{*}{ Points } & \multicolumn{3}{|c|}{ Air temperature $\left({ }^{\circ} \mathrm{C}\right)$} & \multicolumn{3}{|c|}{ Relative humidity (\%) } & \multicolumn{3}{|c|}{$\operatorname{ET}\left({ }^{\circ} \mathrm{C}\right)$} \\
\hline & Average & Max & Min & Average & Max & Min & Average & Max & Min \\
\hline \multicolumn{10}{|c|}{ Dry season } \\
\hline P01 & 27.2 & 28.6 & 24.1 & 81.5 & 100.0 & 70.7 & 25.7 & 26.6 & 24.2 \\
\hline P02 & 27.7 & 28.9 & 24.3 & 76.6 & 97.7 & 68.4 & 25.9 & 26.9 & 24.2 \\
\hline P03 & 28.8 & 30.1 & 24.9 & 77.1 & 98.2 & 68.2 & 26.9 & 27.9 & 24.8 \\
\hline P04 & 28.4 & 29.6 & 24.8 & 75.6 & 95.8 & 67.2 & 26.4 & 27.4 & 24.5 \\
\hline P05 & 27.7 & 28.8 & 24.5 & 78.7 & 97.6 & 70.8 & 26.1 & 27.0 & 24.3 \\
\hline P06 & 27.7 & 29.1 & 24.2 & 78.4 & 99.3 & 68.8 & 26.0 & 26.9 & 24.2 \\
\hline P07 & 27.7 & 29.0 & 24.4 & 79.1 & 98.4 & 69.3 & 26.0 & 27.0 & 24.3 \\
\hline P08 & 27.7 & 29.1 & 24.4 & 79.0 & 99.1 & 70.1 & 26.1 & 27.1 & 24.4 \\
\hline P09 & 28.2 & 29.4 & 24.6 & 75.3 & 95.6 & 65.5 & 26.2 & 27.1 & 24.4 \\
\hline Average & 27.9 & 29.2 & 24.4 & 77.9 & 98.0 & 68.7 & 26.1 & 27.1 & 24.3 \\
\hline \multicolumn{10}{|c|}{ Rainy season } \\
\hline P01 & 24.3 & 25.2 & 23.0 & 89.8 & 100.0 & 77.9 & 23.4 & 24.2 & 22.8 \\
\hline P02 & 24.9 & 26.1 & 22.7 & 86.0 & 99.6 & 74.7 & 24.0 & 25.5 & 22.7 \\
\hline P03 & 25.4 & 27.6 & 22.9 & 81.7 & 96.9 & 68.6 & 24.2 & 25.8 & 22.7 \\
\hline P04 & 25.2 & 26.8 & 22.9 & 83.5 & 97.5 & 69.5 & 24.1 & 25.6 & 22.8 \\
\hline P05 & 24.9 & 27.0 & 22.5 & 85.9 & 100.0 & 73.2 & 24.0 & 25.7 & 22.5 \\
\hline P06 & 25.1 & 26.7 & 22.7 & 85.0 & 99.2 & 72.5 & 24.0 & 25.6 & 22.7 \\
\hline P07 & 25.1 & 27.0 & 22.7 & 84.0 & 99.3 & 72.6 & 24.0 & 25.7 & 22.7 \\
\hline P08 & 25.2 & 27.3 & 22.7 & 83.9 & 98.9 & 72.8 & 24.1 & 25.5 & 22.8 \\
\hline P09 & 25.4 & 28.0 & 22.7 & 86.3 & 100.0 & 73.0 & 24.4 & 26.2 & 22.8 \\
\hline Average & 25.0 & 26.8 & 22.7 & 85.0 & 99.0 & 72.7 & 24.0 & 25.5 & 22.7 \\
\hline
\end{tabular}


Table 5. Percentages of land cover for each observation point.

\begin{tabular}{lccccccccc}
\hline Land cover & P01 & P02 & P03 & P04 & P05 & P06 & P07 & P08 & P09 \\
\hline Type I & 1.23 & 44.06 & 34.21 & 16.90 & 51.12 & 74.97 & 26.19 & 18.38 & 60.48 \\
Type II & 0.08 & 1.40 & 5.13 & 4.57 & 0.77 & 0.34 & 2.46 & 7.52 & 0.00 \\
Type III & 0.00 & 1.51 & 2.37 & 0.91 & 1.79 & 0.11 & 0.58 & 2.89 & 0.29 \\
Type IV & 1.04 & 0.34 & 0.29 & 0.56 & 0.01 & 0.00 & 0.00 & 0.07 & 0.02 \\
Type V & 0.00 & 0.00 & 0.00 & 0.00 & 0.00 & 0.00 & 0.00 & 0.00 & 0.00 \\
Type VI & 1.72 & 4.27 & 5.34 & 8.66 & 3.83 & 0.00 & 2.28 & 11.28 & 9.59 \\
Type VII & 0.00 & 24.25 & 40.00 & 29.97 & 22.12 & 0.14 & 21.23 & 39.66 & 6.26 \\
Type VIII & 11.9 & 4.49 & 4.20 & 8.14 & 8.81 & 5.87 & 36.50 & 6.37 & 7.74 \\
Type IX & 84.84 & 19.69 & 8.46 & 30.28 & 11.55 & 18.78 & 10.74 & 13.83 & 15.61 \\
\hline
\end{tabular}

Type V land cover is absent, whereas type IV cover is rare within the study area. Therefore, bodies of water do not produce positive effects on an individual's thermal perception. The quality and quantity of land cover affects the balance of energy of humans, and thus has strong implications for thermal comfort. In addition, different types of land cover have complex surface structures that determine the specific microclimatic qualities of an environment. The effect of vegetation on microclimates during the daytime results from the reduced penetration of solar radiation to the ground and through the walls due to partial shading (Hassaan and Mahmoud, 2011).

Asphalt (Type VI) and concrete (Type VII) pavement produced microclimate effects, and therefore contributed to an increase in the ET at points P03, P04 and P05. These pavement materials absorb solar and infrared radiation and dissipate a portion of the accumulated heat to the atmosphere via convective and radiative processes, thereby increasing the ambient temperature (Akbari et al., 2001). João Pessoa is a coastal city with a warm and humid climate, and therefore building-system interactions play a significant role in thermal comfort. This study demonstrated that areas with a high density of ceramic roofing tiles and asphalt pavement have the highest temperatures and ET values, which are related to the thermal properties of these structures. In contrast, the most comfortable areas in the city were closest to vegetated areas, which had comfort levels similar to those of the rural area (Mata do Buraquinho). According to Table 4, the average air temperature, the relative humidity and the ET index at each analyzed point for both seasons throughout 2015 showed thermal perception ratios that were clearly outside the comfort zone, according to the adjusted ET range. The exception to this trend was the reference point (rural area) during the rainy season. The minimum values of the ET index in the mornings were in the comfortable and partially comfortable ranges during the rainy and dry seasons, respectively. However, in the afternoons, the maximum ET values were uncomfortable during the dry season and varied from partially comfortable to uncomfortable during the rainy season.

Evaluation of the ET values during the dry season shows that the thermal comfort in most cases was significantly reduced relative to the rainy season; i.e., the comfort level changed from a superior to inferior range at all monitored points according to the classifications using the adjusted ET. The minimum ET values at point P01 tended to be slightly higher than at point P02 during the rainy season, although these values were equal in the dry season. However, appreciable differences in the ET index values during the dry season were, respectively, $6.1 \%$ and $6.6 \%$ higher than those during rainy season. In general, the relative humidity was high throughout the seasons. The results also show that difference in the ET between the measuring points was as high as $7.5 \%-8.7 \%$ due to the different abundances of permeable and impermeable materials. 
Complex urban environments can result in very different and often extreme comfort sensations even within short distances (Gulyás et al., 2006). These differences are statistically significant according to the Mann-Kendall test $(\mathrm{p}<0.05)$. The air temperature increased between the 1980s and the 2010s, which corresponds to a period of rapid urbanization in this city. These trends were used to determine future scenarios of thermal comfort conditions and to compare these predictions to the comfort limits specified by current standards. These findings are particularly important because specific meteorological conditions, including high temperatures, low cloud cover, and low average wind speeds, tend to intensify the heat island effect. To quantify the bioclimatic conditions throughout the study area, air temperature and relative humidity trends from meteorological stations close to an urban area were used to assess the impact of urban development on thermal stress. Figure 2 shows the trends in air temperature and relative humidity in the study area for the period 1968-2015. Air temperature shows an increasing trend of $0.34^{\circ} \mathrm{C} /$ decade, whereas relative humidity shows a decreasing trend of $0.49 \% /$ decade, as calculated using annual mean data.

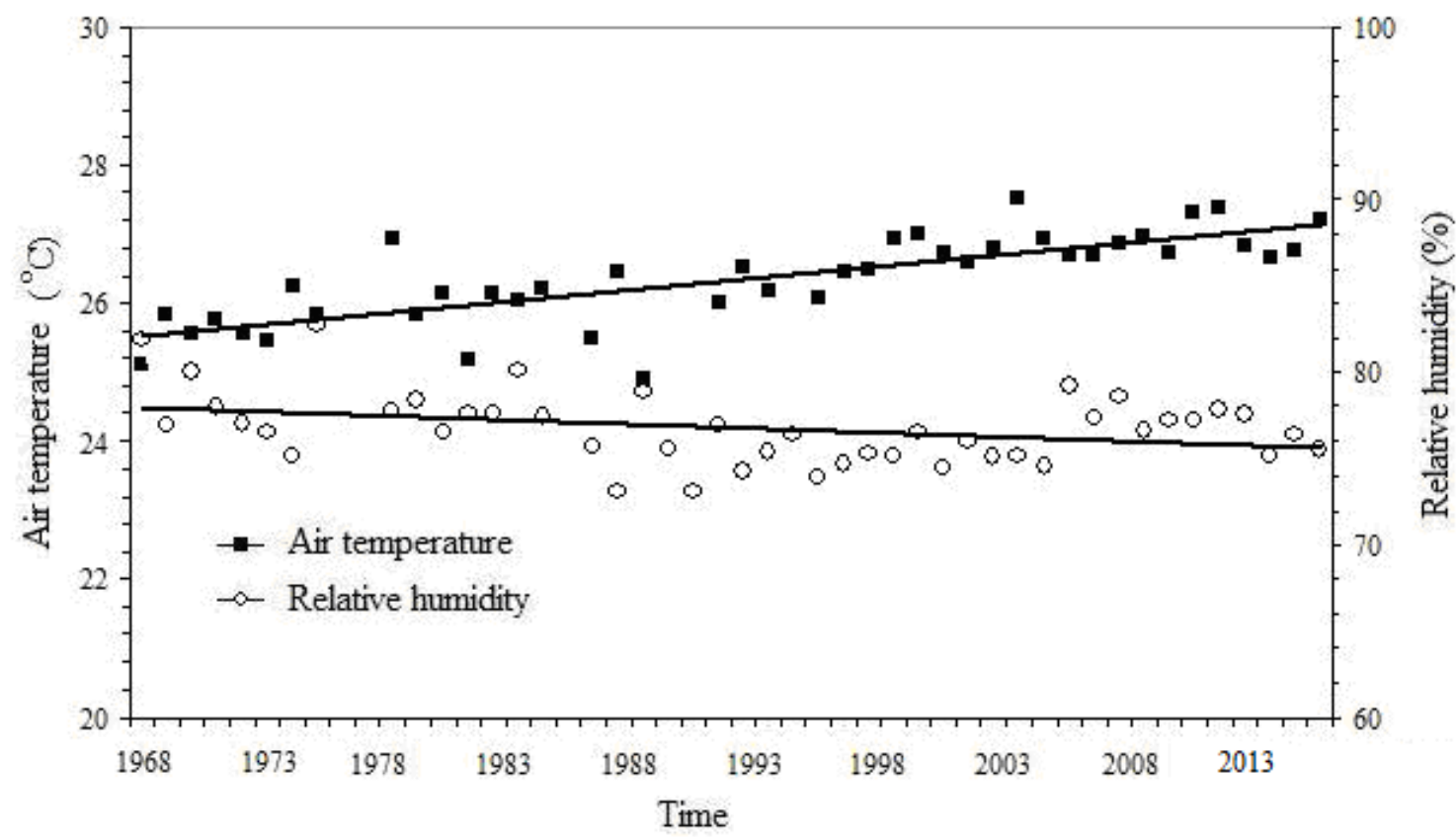

Figure 2. Trends in air temperature and relative humidity in the study area for the period of 1968-20115.

Trend in wind speed in João Pessoa during analyzed periods is shown in Figure 3. The seasonal wind speed pattern in the study area is increasing with a trend of $0.15 \mathrm{~ms}^{-1} / \mathrm{decade}$. This trend is statistically significant according to the Mann-Kendall test at the $5 \%$ confidence level. Wind speed values range from a minimum of $1.3 \mathrm{~ms}^{-1}$ to a maximum of $3.80 \mathrm{~ms}^{-1}$ with average \pm standard deviation of $2.91 \pm 0.61 \mathrm{~ms}^{-1}$. When discussing the effects of urban design and meteorological parameters on thermal comfort for pedestrians at street level, Kleerekoper et al. (2017) observed that wind is among the four main thermal comfort indicators, and is therefore an important parameter to be used in any urban climate index. Using the MannKendall test for analyzing climate trends on the extreme winds in Brazil, Pes et al. (2017) observed that trends in minimum wind speed series are not conclusive because they show disparate results between homogeneous regions.

Figure 3 also shows that there is no trend in the wind data if we consider only the 19792008 timeframe and a significant fall in the wind speed trend post 2008. This decrease can be linked objectively to the urban expansion in the last years. Silva (2004) found for João Pessoa an increasing trend in air temperature of $0.025^{\circ} \mathrm{C} /$ year and a decreasing trend in relative

\section{IPABH}

Rev. Ambient. Água vol. 13 n. 5, e2092- Taubaté 2018 
humidity of $0.10 \% / y e a r$, both statistically significant at $\mathrm{p}<0.01$ level. He also observed an increasing trend in Class A pan evaporation and reference evapotranspiration, which are indicative of a decreasing trend in wind speed. The results of the present study agree with those reported by Silva (2004). When analyzing the spatiotemporal impact of land use and land cover changes on urban heat islands in Maranhão State, Brazil, Silva et al. (2018) observed that many areas experienced extensive urbanization over the 16-year study period, which resulted in the loss of green spaces and increased urban heat island.

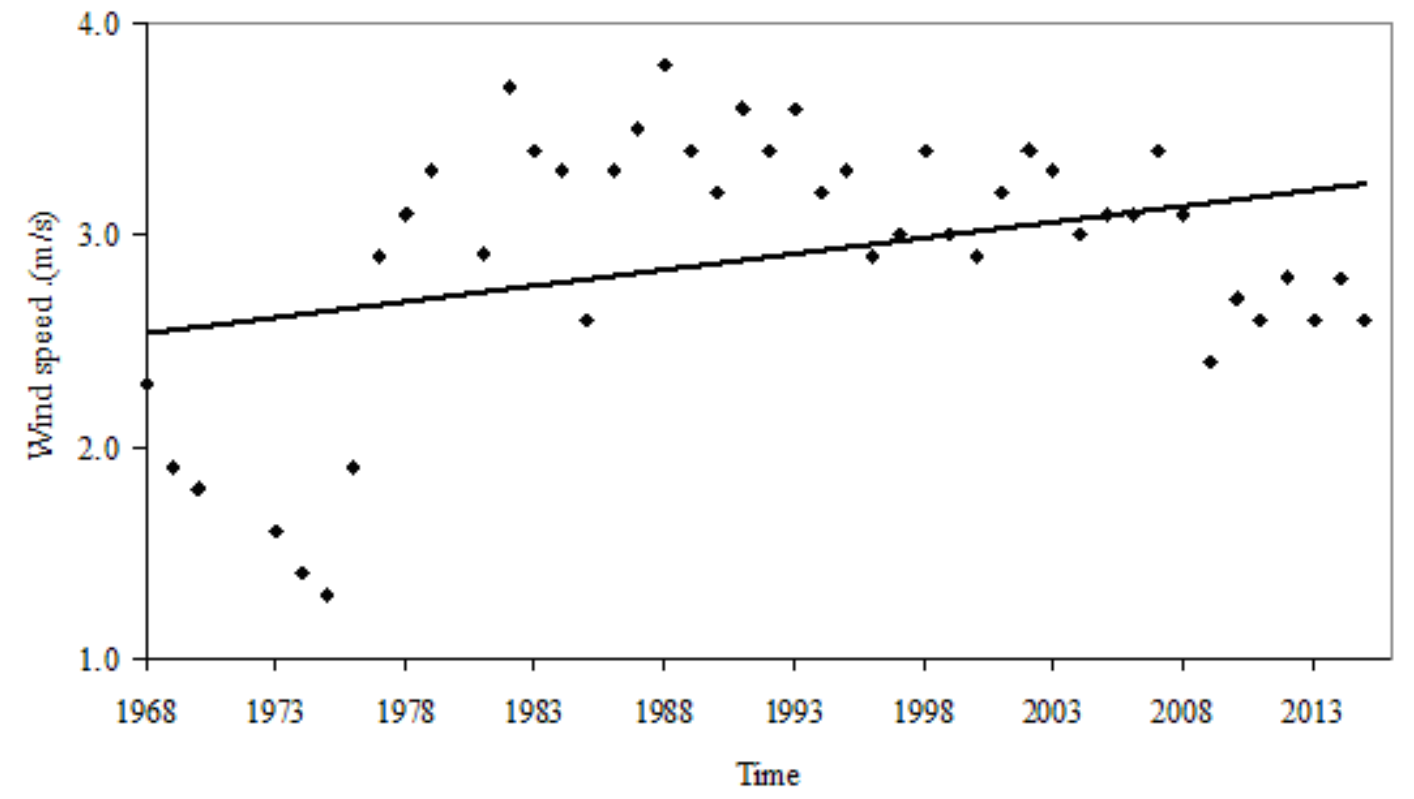

Figure 3. Trends in air wind speed in the study area for the period of 1968-20115.

The spatial distribution of the human thermal comfort level in João Pessoa for current climate conditions and for the 2020s, the 2030s, the 2040s, the 2050s and the 2060s are depicted for both the dry and rainy seasons in Figures 4 and 5, respectively. It is apparent that there is a large discrepancy in the thermal sensations between the two seasons. For the current weather conditions, the areas surrounding point P01 are partially comfortable, whereas the remainder of the city is uncomfortable during the dry season (Figure 4A). Except for the comfortable level of the reference area (point P01), the city is partially comfortable during the rainy season (Figure 5A). In the coastal area, large differences in the air temperature and ET index occur during the dry season relative to the rainy season. For the dry season, results for the scenarios from the 2020s to the 2050s indicate that the entire city is uncomfortable during the dry season due to a sensation of heat that varies between approximately $27^{\circ} \mathrm{C}$ (point P01) and $30^{\circ} \mathrm{C}$ (point P03). For the scenario in the 2060s (Figure 4F), points P03 and P04 became very uncomfortable, with air temperatures in the range $28.9-30.5^{\circ} \mathrm{C}$, and the remaining area is uncomfortable. Thermal conditions during the rainy season will tend to be less rigorous for the scenarios from the 2020s to the 2050s. Because building-system interactions play a significant role in thermal perception, it is reasonable that points P02 and P03 show a high discomfort level. The intensity of external heat loads in these areas is more dependent on the solar radiation and orientation of the building (east-west or north-south) than on wind speed. Although wind is an important factor for mitigating the heat stress of an urban area, the obstacles created by high-rise buildings prevent the flow of wind from the ocean.

The simulated ET index also revealed significant changes in human thermal comfort for the rainy season, particularly in the coastal area, for the 2060s scenario. The reference point (Mata do Buraquinho) changes from comfortable to partially comfortable during this season, 
whereas the coastal area (points P03, P04 and P09) changes from partially comfortable to uncomfortable. This indicates an overall difference of 5.5\% and 6.4\% during dry and rainy seasons, respectively. The temperature in the coastal area is primarily influenced by buildings and asphalt pavement that trap solar radiation. In contrast, the air temperature at the reference area is influenced by vegetation that maintains a temperature lower than that in the other areas of the city as a consequence of evapotranspiration by abundant vegetation. The relatively comfortable areas within the city for both current weather conditions and future scenarios are those closer to vegetation. Point P02 is the second-most comfortable area among the measuring points, which may be attributable to the green areas surrounding the reference point. In summary, the area of comfortable conditions surrounding point P01 appears during dry and rainy seasons due to evapotranspiration by native vegetation, which results in lower temperatures in comparison to other points in the city.

Inversely, uncomfortable conditions near point P03 are caused by heat that is accumulated by the impervious surfaces or building materials (e.g., concrete and asphalt) during the day. This result agrees with the observations of Hassaan and Mahmoud (2011) who analyzed the microclimatic and human comfort conditions in an urban park in hot and arid regions. They documented that the thermal requirements of people and the qualities of the local climate should be carefully considered when designing the landscapes of urban parks in hot and arid regions. The temperatures were found to be highest near the coastal area, and the temperature gradient increases from the coastal area towards the reference point. The horizontal surface temperature gradient can be used to determine the cooling effect of vegetation relative to the urban effect. Air temperature has been increasing at a rate of $0.034^{\circ} \mathrm{C} /$ year during the last 48 years with predicted values as high as $30.5^{\circ} \mathrm{C}$ in the $2060 \mathrm{~s}$. The maximum predicted value is only $28.9^{\circ} \mathrm{C}$ at the reference point, in agreement with the presence of vegetation. There is a sharp increase in the ET values at point P03 when the ET reaches very uncomfortable conditions in the 2050s, whereas the remaining area has uncomfortable conditions during the dry season.

The highest recorded air temperature at points P03, P04 and P09 are attributable to different types of cover, such as aluminum roofing tiles, asphalt pavement and concrete pavement. A major problem associated with the use of those materials in warm weather is that they absorb and retain enormous amounts of heat, which leads to an increase in air temperature. Therefore, the level of human thermal comfort has been increasing throughout these areas due to the substitution of vegetation for building materials. These data indicate that the range of ET index corresponds to a thermal sensation between uncomfortable in the dry season and comfortable/partially comfortable in the rainy season for the current weather conditions. This study indicates that physiological responses are determined primarily by changes in air temperature.

Air temperature (Figure 6) is also significantly different in the dry season relative to the rainy season along the coastal area, which affects the heat stress in the urban area. The air temperature varies between $24.6-25.5^{\circ} \mathrm{C}$ during the rainy season (Figure 6A) and varies between $27.2-28.8^{\circ} \mathrm{C}$ among the measurement points during the dry season (Figure 6B). The small differences in temperatures can be explained by the relatively short distances between the measuring points. However, large differences in relative humidity are observed among the measurement points; e.g., the relative humidity varies by $7.8 \%$ and $9.9 \%$ during dry and rainy seasons, respectively. 


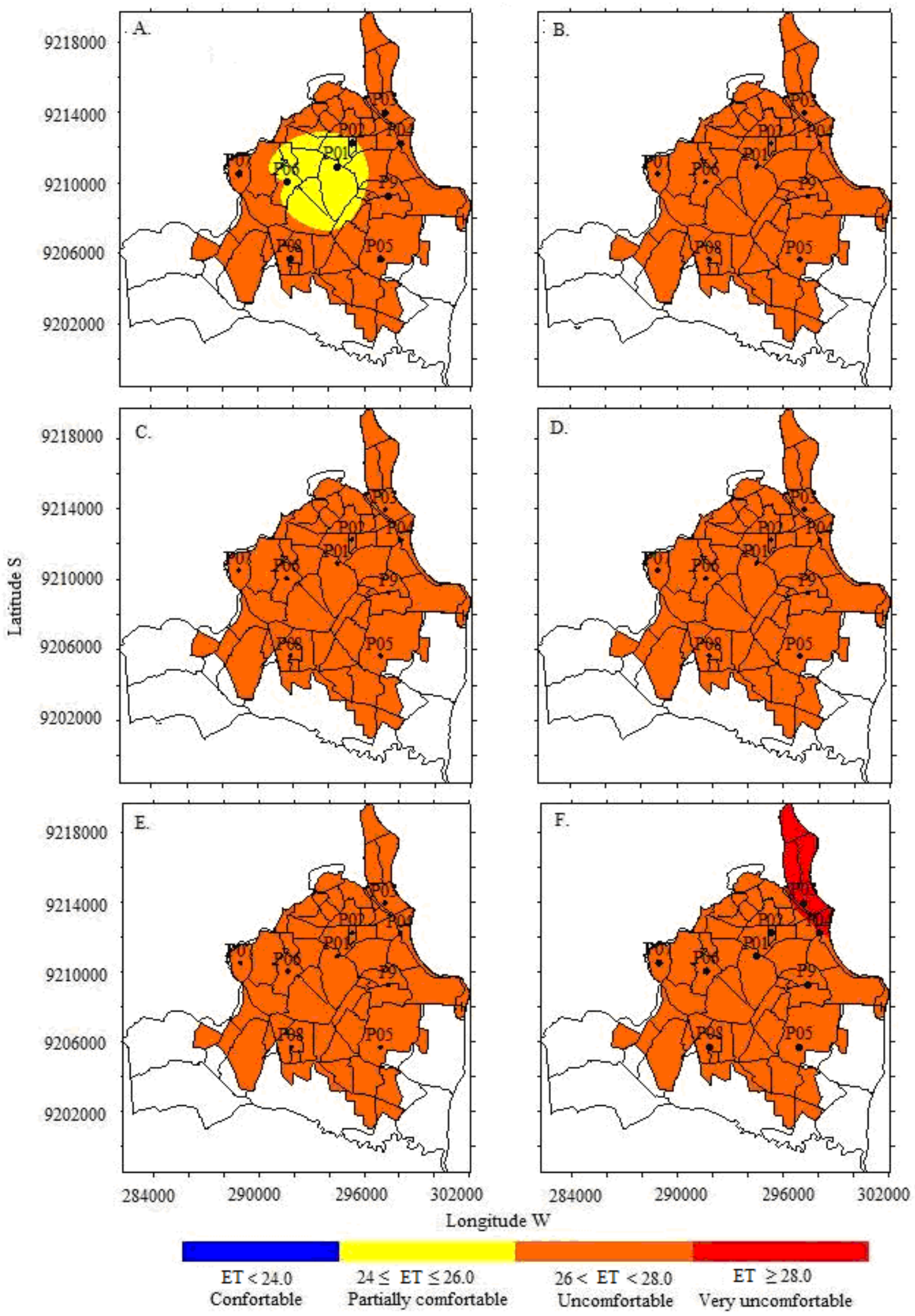

Figure 4. Spatial distribution of human comfort levels in 2010s (A) and in scenarios for 2020s (B), 2030s (C), 2040s (D), 2050s (E) and 2060s (F) during the dry season within the study area. Latitudes and longitudes are shown using the Universal Transverse Mercator (UTM) geographic coordinate system. 


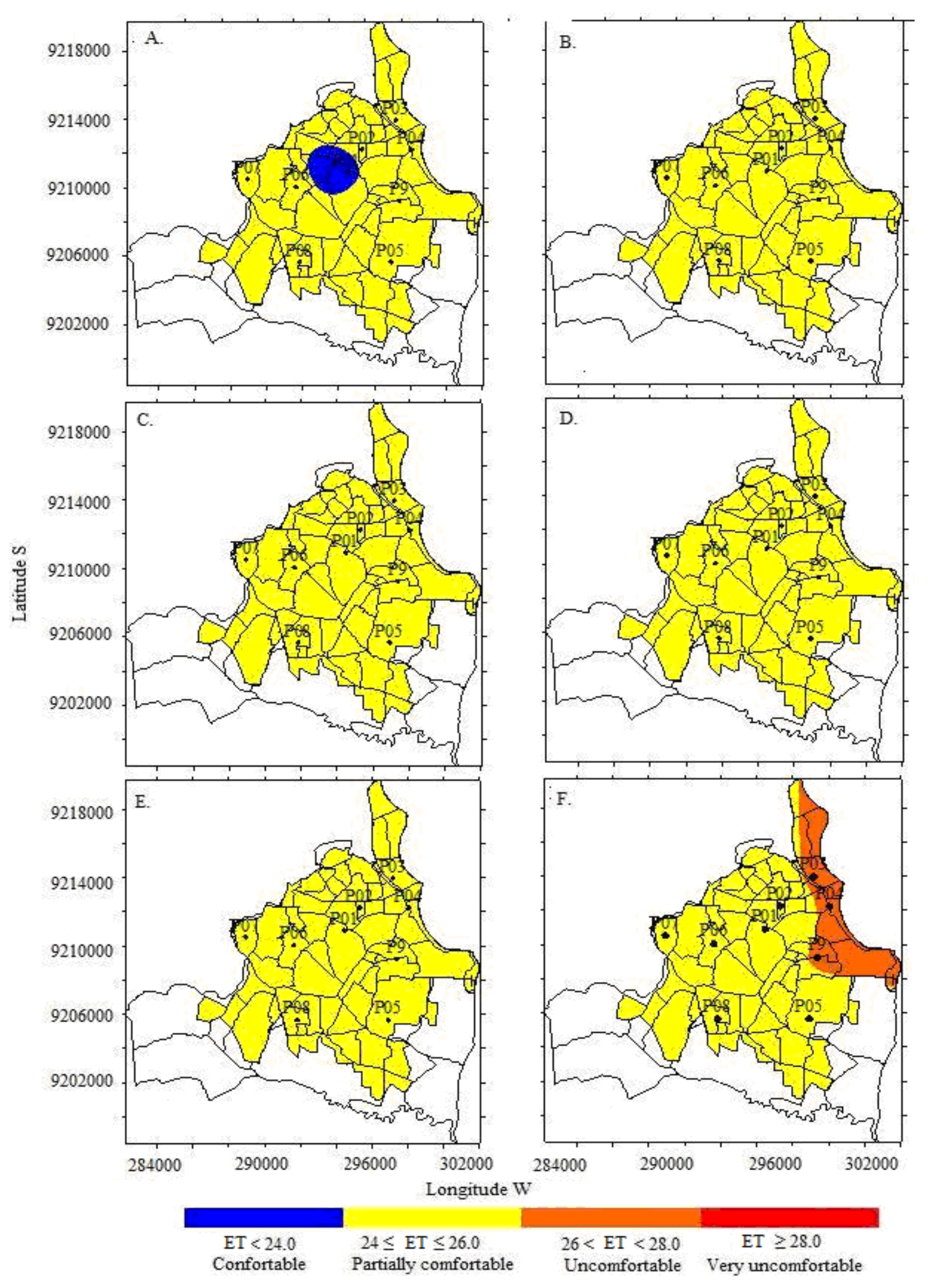

Figure 5. Spatial distribution of human comfort levels in 2010s (A) and in scenarios for 2020s (B), 2030s (C), 2040s (D), 2050s (E) and 2060s (F) during the rainy season within the study area. Latitudes and longitudes are shown using the Universal Transverse Mercator (UTM) geographic coordinate system.

\section{IPABH}




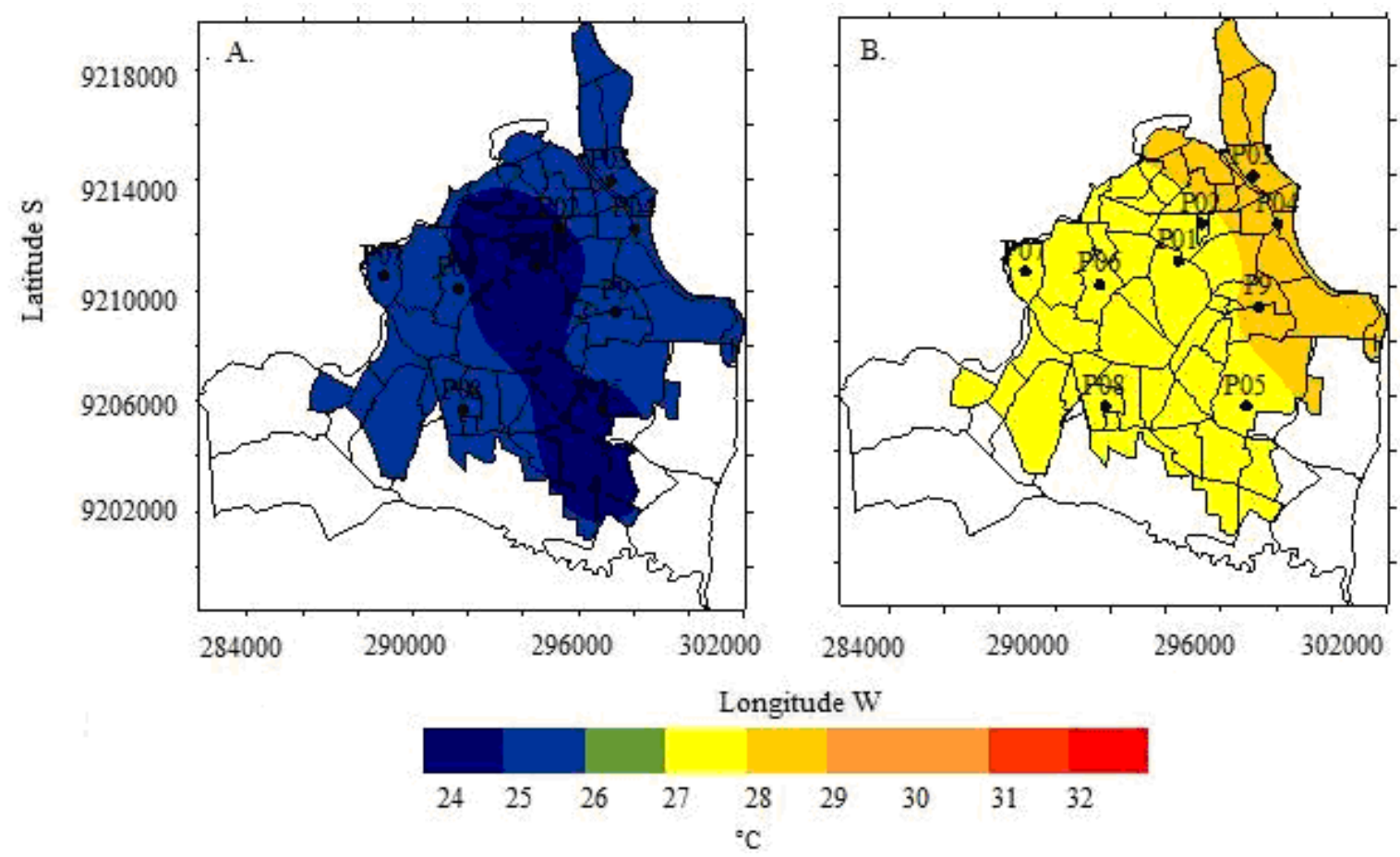

Figure 6. Spatial distribution of air temperatures in 2015 during the rainy (A) and dry (B) seasons within the study area.

Although points P03 and P04 are located near the coastal zone, they have an uncomfortable condition according to the adjusted ET index. The combined effects of high temperature, high moisture content and changes in the urban landscape can explain these results. Another reason for the high thermal conditions is that the surface materials in that zone have a high albedo, which reflects a large amount of radiation to the surrounding objects; that area is also not surrounded by any vegetation. Although studies have shown that areas $10-20 \mathrm{~m}$ from the water's edge show the greatest improvement in thermal comfort (Xu et al., 2010) changes in the biodiversity and aesthetics of urban landscapes in littoral areas can have a synergistic effect, thereby reducing the effects of the water body on human thermal comfort.

\section{CONCLUSIONS}

This paper has studied the bioclimatic conditions for future scenarios for João Pessoa, a humid tropical city located in Brazil. This study indicates that physiological responses are determined primarily by changes in air temperature. Wind speed can be considered a valuable climatic variable for purpose of urban climate studies. Land cover changes produce effects on evaporation/evapotranspiration and therefore on human comfort level. There is a clear increasing trend in outdoor temperatures and decreasing trend in relative humidity levels in the study area. Current and future environmental conditions are likely to shift towards a warmer atmosphere due to urbanization processes. The effects of these changes on people will be more pronounced during the dry season when the human thermal comfort will change from comfortable to very uncomfortable throughout most of the city. The projection of climate variables from 2010 to 2060 in the hottest area of the city demonstrate a large air temperature increase of up to $2^{\circ} \mathrm{C}$, whereas the relative humidity is reduced by up to $2.5 \%$. Highly uncomfortable conditions are predicted for the period of 2050 to 2060 throughout João Pessoa city. 


\section{REFERENCES}

AKBARI, H.; POMERANTZ, M.; TAHA, H. Cool surfaces and shade trees to reduce energy use and improve air quality in urban areas. Solar Energy, v. 70, n. 1, p. 295-310, 2001.

GULYÁS, A.; UNGER, J.; MATZARAKIS, A. Assessment of the microclimatic and human comfort conditions in a complex urban environment: Modeling and measurements. Building and Environment, v. 41, p. 1713-1722, 2006.

HAN, J.; YANG, W.; ZHOU, J.; ZHANG, G.; ZHANG, Q.; MOSCHANDREAS, D. J. A. Comparative analysis of urban and rural residential thermal comfort under natural ventilation environment. Energy Building, v. 41, p. 139-145, 2009.

HASSAAN, A.; MAHMOUD, A. Analysis of the microclimatic and human comfort conditions in an urban park in hot and arid regions. Building and Environment, v. 46, p. 26412656, 2011.

JUSUF, S. K.; WONG, N. H.; HAGEN, E.; ANGORRO, R.; HONG, Y. The influence of land use on the urban heat island in Singapore. Habitat International, v. 31, p. 232-242, 2007.

KATZSCHNER, L.; BOSCH, U.; RÖTTGEN, M. Behaviour of people in open spaces in dependence of thermal comfort conditions. In: CONFERENCE ON PASSIVE AND LOW ENERGY ARCHITECTURE, 23., 2006, Proceedings... Genève: Université de Genève, 2006.

KENDALL, M. G. Rank correlation measures. London: Charles Griffin, 1975. 220p.

KLEEREKOPER, L.; TALEGHANI, M.; VAN DEN DOBBELSTEEN, A.; HORDIJK, T. Urban measures for hot weather conditions in a temperate climate condition: A review study. Renewable and Sustainable Energy Reviews, v. 75, p. 515-533, 2017.

KOLOTRONI, M.; GIRIDHARAN, R. Urban heat island intensity in London: an investigation of the impact of physical characteristics on changes in outdoor air temperature during summer. Solar Energy, v. 82, p. 986-988, 2008.

KRÜGER, E. L.; MINELLA, F. O.; RASIA, F. Impact of urban geometry on outdoor thermal comfort and air quality from field measurements in Curitiba, Brazil. Building and Environment, v. 46, p. 621-634, 2011.

KRÜGER, E. L.; DRACH, P. R. C. Interferências do fator cor da pele na percepção térmica de transeuntes. Ambiente Construído, v. 17, n. 1, p. 83-96, 2017.

LI, P.W.; CHAN S. T. Application of a weather stress index for alerting the public to stressful weather in Hong Kong. Journal of Climate and Applied Meteorology, v. 7, p. 369-375, 2000.

LOBACCARO, G.; CARLUCCI, S.; CROCE, S.; PAPARELLA, R.; FINOCCHIARO, L. Boosting solar accessibility and potential of urban districts in the Nordic climate: A case study in Trondheim. Solar Energy, v. 149, p. 347-369, 2017.

MANN, H. B. Econometrica. The econometric society, v. 13, p. 245-259, 1945.

MATZARAKIS, A.; RUTZ F.; MAYER, H. Model-ling Radiation fluxes in simple and complex environments - Basics of the RayMan model. International Journal of Biometeorology, v. 54, p. 131-139, 2010. 
MEMON, R. A.; LEUNG, D. Y. C.; CHUNHO, L. A review on the generation, determination and mitigation of Urban Heat Island. Journal of Environmental Sciences, v. 20, p. 120128, 2008.

PES, M. P.; PEREIRA, E. B.; MARENGO, J. A.; MARTINS, F. R.; HEINEMANN, D.; SCHMIDT, M. Climate trends on the extreme winds in Brazil. Renewable Energy, v. 109, p. 110-120, 2017.

RAFAEL, S.; MARTINS, H.; MARTA-ALMEIDA, M.; SÁ, E.; COELHO, S.; ROCHA, A. et al. Quantification and mapping of urban fluxes under climate change: Application of WRF-SUEWS model to Greater Porto area (Portugal). Environmental Research, v. 155, p. 321-344, 2017.

ROBAA, S. M. Thermal Human Comfort in Egypt. International Journal of Meteorology, v. 283, p. 359-371, 2003.

SALVATI, A.; ROURA, H. C.; CECERE, C. Assessing the urban heat island and its energy impact on residential buildings in mediterranean climate: Barcelona case study. Energy and Buildings, v. 146, p. 38-54, 2017.

SILVA, V. P. R. On climate variability in Northeast of Brazil. Journal of Arid Environments, v. 58, p. 575-596, 2004.

SILVA, V. P. R.; SOUSA, F. A. S.; CAVALCANTI, E. P.; SOUZA, E. P.; SILVA, B. B. Teleconnections between sea-surface temperature anomalies and air temperature in northeast Brazil. Journal of Atmospheric and Solar-Terrestrial Physics, v. 68, p. 781792, 2006.

SILVA, V. P. R.; AZEVEDO, P. V.; BRITO, R. S.; CAMPOS, J. H. B. C. Evaluating the urban climate of a typically tropical city of northeastern Brazil. Environmental Monitoring Assessment, v. 161, n. 1, p. 45 - 59, 2010.

SILVA, J. S.; SILVA, R. M.; SANTOS, C. A. G. Spatiotemporal impact of land use/land cover changes on urban heat islands: A case study of Paço do Lumiar, Brazil. Building and Environment, v. 136, p. 279-292, 2018.

TONG, H.; WALTON, A.; SANG, J.; CHAN, C. L. Numerical simulation of the urban boundary layer over the complex terrain of Hong Kong. Atmospheric Environment, v. 9, n.1, p. 3549-3563, 2005.

TSELIOU, A.; TSIROS, I. X.; LYKOUDIS, S.; NIKOLOPOULOUM, M. An evaluation of three biometeorological indices for human thermal comfort in urban outdoor areas under real climatic conditions. Building and Environment, v. 45, p. 1346-1352, 2010.

VEREMCHUK, L. V.; YANKOVA, V. I.; VITKINA, T. I.; NAZARENKO, A. V.; GOLOKHVAST, K. S. Urban air pollution, climate and its impact on asthma morbidity. Asian Pacific Journal of Tropical Biomedicine, v. 6, p. 76-79, 2016.

YU, C.; HIEN, W. N. Thermal benefits of City Parks. Energy and Buildings, v. 38, p. 105120, 2006.

XU, J.; WEI, Q.; HUANG, X.; ZHU, X.; LI, G. Evaluation of human thermal comfort near urban waterbody during summer. Building and Environment, v. 45, p. 1072-1080, 2010.

WU, J.; FRANZÉN, D.; MALMSTRÖM, M. E. Nutrient flows following changes in source strengths, land use and climate in an urban catchment, Råcksta Träsk in Stockholm,Sweden. Ecological Modelling, v. 338, p.69-77, 2016. 